\title{
Ecology \\ Diversity of flesh flies (Diptera: Sarcophagidae) in an Atlantic forest fragment in Rio das Ostras, RJ, Southeastern Brazil
}

\author{
Marina Morim Gomes ${ }^{\bowtie(\bullet)}$ \& Cátia Antunes de Mello-Patiu ${ }^{\circledR}$
}

Laboratório de Diptera Neotropicais - DIPNEO, Departamento de Entomologia, Museu Nacional, UFRJ, Rio de Janeiro, RJ, Brazil.

\section{EntomoBrasilis 14: e940 (2021)}

\section{Edited by:}

Alberto Moreira Silva-Neto

\section{Article History:}

Received: 15.i.2021

Accepted: $02 . i i i .2021$

Published: 23.iii.2021

\section{Corresponding author:}

Marina Morim Gomes

乃 gomes.mari.95@gmail.com

Funding agencies:

$\therefore$ FAPERJ (Fundação Carlos Chagas Filho de Amparo à Pesquisa no Estado do Rio de Janeiro; CNPq (Conselho Nacional de Desenvolvimento Científico e Tecnológico)

\begin{abstract}
Sarcophagidae is a family of Diptera with medical-veterinary importance, which have species with sarcosaprophagous, necrophagous or causing-myiasis larvae, among others. The Brazilian state of Rio de Janeiro has 92 municipalities, but only 26 have sarcophagid records and the municipality of Rio das Ostras is one of the least registered, with only nine species recorded. This works aimed to increase the knowledge of flesh fly diversity in a conservation unit of this municipality, the "Área de Relevante Interesse Ecológico de Itapebussus". The study was conducted in restinga and semideciduous forest. We used modified Van Someren-Rydon traps baited with decayed fish, and the samples were taken in dry and rainy seasons. A total of 446 male sarcophagines of 18 species of the genera Oxysarcodexia, Peckia, Ravinia, Sarcofahrtiopsis, and Titanogrypa were collected. We found 13 new records for the sampled municipality. The forest presented higher richness than the restinga and the most abundant species was Oxysarcodexia amorosa (Schiner). Diversity and equitability showed similar values in the two areas $\left(H^{\prime} f=2.193, H^{\prime} r=2.027, J^{\prime} f=0.7908\right.$ and $\left.J^{\prime} r=0.7682\right)$ and the cluster analysis suggest high similarity. PERMANOVA did not present significant results for any source of variation. The presence of synanthropic and asynanthropic species in the fragment demonstrates that it is already a somewhat human-impacted environment. Marked increase in the number of sarcophagid records obtained in this small sample in the studied municipality (from nine to 22 species) shows the importance of taxonomic surveys in poorly studied areas.
\end{abstract}

Keywords: Biodiversity; Inventory; Neotropical; Lowland Forest; Restinga.
Parcophagidae, a family of Calyptratae Diptera, include dull gray muscoid dipterans with three longitudinal black stripes on mesonotum, abdomen checkered, a row of setae in the meron, and undeveloped subscutellum (SHEWELL 1987). There are more than 3,000 described species and they are distributed in all biogeographic areas (PAPE 1996; PAPE et al. 2011). Sarcophaginae, the most diverse of the three subfamilies, shows also a high habit diversity, mainly saprophagy (PAPE 1996). Sarcossaprophagous sarcophagids play a fundamental role in nutrient cycling in ecosystems and the decomposition of carcasses (BYRD \& CASTNER 2001). Thus, they are important to forensic entomology and have been the subject of many works of applied science (CARVALHO \& Linhares 2001; Oliveira-Costa et al. 2001; Barros et al. 2008; Pujol-Luz et al. 2008; Rosa et al. 2009; Alves et al. 2014; Dias et al. 2015). Moreover, some species are synanthropic, i.e., they can survive in the human-impacted environments (LINHARES 1981; YePES-GaURISAs et al. 2013) and can be used as potential bioindicators (BARBosa et al. 2017; Sousa et al. 2014).

Rio das Ostras is a municipality in the region of "Baixadas Litorâneas", state of Rio de Janeiro, Southeastern Brazil, a coastal region known for intense tourist activities that have generated high environmental degradation (RIBEIRO 2003; Mascarenhas 2004). The municipality is located in the Atlantic rainforest biome and has original vegetation cover of lowland and submontane forest (MAYERHOFER \& Toledo 2004). Atlantic rainforest is a worldwide hotspot and actually has only $7 \%$ of its original coverage, with high fragmentation (MYeRs et al. 2000; TABarell et al. 2005). Rio das Ostras has two federal and three municipal Conservation Units (UCS), including the municipal Area of Relevant Ecological Interest of Itapebussus (MAYerhofer \& Toledo 2004).

The state of Rio de Janeiro has 92 municipalities, but only 26 have records on sarcophagid diversity, with the Region of "Baixadas Litorâneas" one of the least registered. Only nine species of five genera have scattered records from the municipality of Rio das Ostras (Mello-Patiu et al. 2009) and none of these are recorded from Conservation Units. Accordingly, data about insects from the Region of "Baixadas Litorâneas" in the state of Rio de Janeiro, including muscoid Diptera, are quite incipient and we aimed to contribute with the knowledge of Sarcophagidae biodiversity in the Brazilian Atlantic Forest for fomenting its preservation.

\section{MATERIAL AND METHODS}

The experiment was performed in Fazenda Itapebussus, municipality of Rio das Ostras, Rio de Janeiro state, Brazil, part of the municipal "Área de Relevante Interesse Ecológico de Itapebussus" (Area of Relevant Ecological Interest of Itapebussus), which will be abbreviated from now on as ARIE Itapebussus. The farm had fragments of restinga vegetation and semideciduous forest, besides pasture lands and wetlands (MAYERHOFER \& TOLEDO 2004). The annual rainfall and daily temperature average are $1,150 \mathrm{~mm}$ and $23.5^{\circ} \mathrm{C}$, respectively (MAYERHOFER \& TOLEDO 2004).

Samples were obtained from two areas: semideciduous forest and restinga forest. The semideciduous forest was present 
on slopes and hilltops, occupying most of the Itapebussus ARIE, while the restinga forest was in the whole post-beach areas (MAYERHOFER \& TOledo 2004). The first experimental area, named "forest", was a fragment of lowland forest with a closed canopy, near some wetlands (Figure 1) and the second, named "restinga", was located near the beach, with the predominance of herbaceous and shrubby vegetations and intense light incidence (Figure 1). These areas are $761 \mathrm{~m}$ away from the houses and pastures, $565 \mathrm{~m}$ apart and spatially separated by a lagoon.

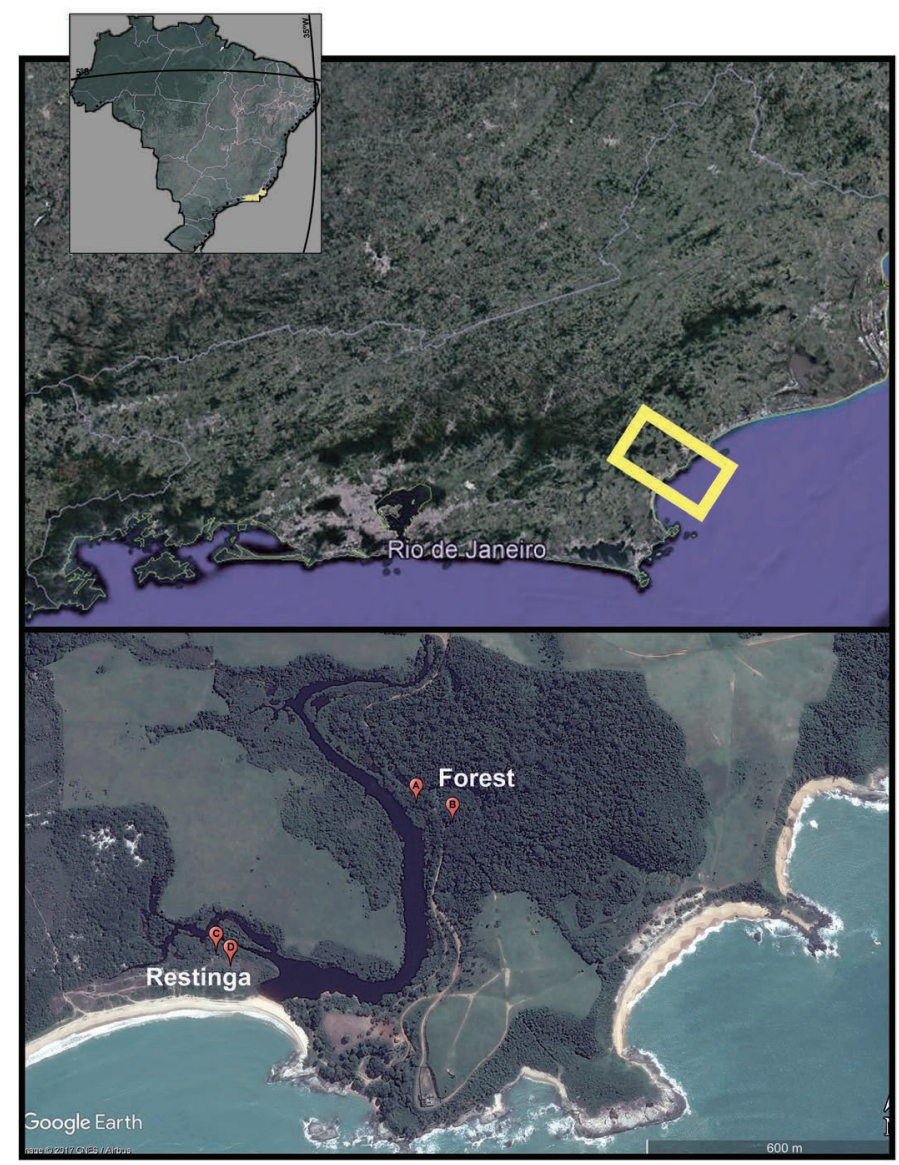

Figure 1. Studied area in forest and restinga of the Area of Relevant Ecological Interest of Itapebussus, municipality of Rio das Ostras, state of Rio de Janeiro, Brazil (images modified from Google Earth Pro; A, B, C, D = georeferenced location of traps).

Specimens were collected in modified Van SomerenRydon traps, suspended approximately $1.20 \mathrm{~m}$ from the ground, baited with decayed fish, previously kept at room temperature for $24 \mathrm{~h}$. They were exposed in the field for 48 hours and the specimens were collected every 24 hours and were installed about 50-100 m apart from each other, depending on the type of terrain and vegetation. In each area, two traps were installed: forest 1 [S 22 $2^{\circ} 28.878^{\prime}$ W41 $1^{\circ} 52.951^{\prime}$ ], forest 2 [S22 $\left.{ }^{\circ} 29.129^{\prime} \mathrm{W} 41^{\circ} 53.161^{\prime}\right]$, restinga 1 [S22 $29.076^{\prime}$ W41 $\left.{ }^{\circ} 53.218^{\prime}\right]$ and restinga 2 [S22 $\left.{ }^{\circ} 29.093^{\prime} \mathrm{W}^{\circ} 1^{\circ} 53.197^{\prime}\right]$ (Figure 1, points $A, B, C$, and $D$, respectively). Two expeditions were conducted, one in the dry season (July 2016) and the other in the rainy season (January 2017), totalizing eight samples.

Trapped adult flesh flies were collected, pinned, and males had their terminalia exposed to allow identification. All male specimens were identified up to the species level, by using an identification key (Carvalho \& Mello-Patiu 2008) and by comparison with material from the "Coleção Entomológica do Museu Nacional/UFRJ" (MNRJ). Species identified were deposited at the same collection (MNRJ), but, unfortunately, all specimens were lost in the fire at the "Museu Nacional" in September 2018.
Weather data from the nearest station were obtained through the INMET portal (Station A608, Macaé, RJ), available on https://www.gov.br/agricultura/pt-br/assuntos/ inmet. Diversity and equitability were calculated using Shannon-Wiener $\left(\mathrm{H}^{\prime}\right)$ and Pielou $\left(\mathrm{J}^{\prime}\right)$ index, respectively. Statistical analyses were performed using the Primer software. PERMANOVA was performed to test if the types of environment (forest or restinga) or period (dry or rainy season) influence sarcophagids abundance and richness. To investigate the similarity between the species composition, a non-metric multidimensional scaling (nMDS) based on a Bray-Curtis matrix and cluster analysis was carried out. The efficiency of the sampling in the studied area was verified using species accumulation curves derived from a secondorder nonparametric Jackknife procedure. Analyzes were performed using a significance level of $5 \%$.

\section{RESULTS}

In total, 446 male specimens were collected, representing 5 genera, and 18 species, all belonging to the subfamily Sarcophaginae (Table 1). Oxysarcodexia and Peckia were the most representative genera, with 8 and 7 species, respectively. Other genera were represented by a single species, with less than $5 \%$ of total abundance. Five species were the most abundant, representing $82.73 \%$ of trapped flesh flies: Oxysarcodexia amorosa (Schiner), Oxysarcodexia intona (Curran \& Walley), Oxysarcodexia thornax (Walker), Oxysarcodexia timida (Aldrich), and Peckia (Peckia) chrysostoma (Wiedemann).

The sampled areas were similar in richness but differed in species composition and abundance. The forest presented 218 specimens and 16 species. Oxysarcodexia xanthosoma (Aldrich), Peckia (Squamatodes) ingens (Walker), Peckia (Euboettcheria) anguilla (Curran \& Waley), Sarcofahrtiopsis cuneata (Townsend), and Titanogrypa (Cucullomyia) larvicida (Lopes) were restricted to the forest. The most abundant species in this area was 0 . amorosa, followed by 0 . thornax. We collected 228 specimens representing 14 species in restinga, with two exclusive species: Oxysarcodexia avuncula (Lopes) and Oxysarcodexia fringidea (Curran \& Walley). The most abundant species in this area was 0 . thornax, followed by $P$. chrysostoma.

The individuals were more abundant in July ( $n=279,62.6 \%$ of total), the season that presented the lowest temperature value $\left(21.7^{\circ} \mathrm{C}\right)$ and higher relative humidity $(84 \%)$. The January expedition, with higher temperatures $\left(27.5^{\circ} \mathrm{C}\right)$, showed a high rate of bait decay by the largest number of deposited larvae, which may have caused lower adults' attractiveness to traps.

Thirteen species were not previously recorded in Rio das Ostras and 12 were not known from the region of "Baixadas Litorâneas" (Table 1). Although new records of 13 species (Table 1) for the municipality correspond to approximately $72 \%$ of the sampled species (18 species), the species accumulation curve was still rising at the end of the study and the estimators calculated that there is a difference of at least four species not collected (Figure 2B). The number of species represents $72.58 \%$ of expected richness according to the Jackknife estimator (Table 2).

Equitability (J'f $\left.=0.7952 ; J^{\prime} r=0.7395\right)$ and the diversity index ( $\left.H^{\prime} f=2.773 ; H^{\prime} r=2.155\right)$ showed that richness and abundance were similar in both areas. No source of variation (phytophysiognomy, period and phytophysiognomy $x$ period) exhibited significant results for the samples ( $p>$ 0.05). In addition, the phytophysiognomy presented $p=$ 0.058 (Table 3) and nMDS analysis with abundance data not presented a clear grouping between areas (Figure 2A). 
Table 1. Absolute $(\mathrm{N})$ and relative abundance (RF) of Sarcophagidae species collected from the Area of Relevant Ecological Interest of Itapebussus, municipality of Rio das Ostras, state of Rio de Janeiro, Brazil, in July 2016 and January 2017 (only males are included). Species in bold are new records for the municipality.

\begin{tabular}{|c|c|c|c|c|c|c|}
\hline \multirow{2}{*}{ Species } & \multicolumn{2}{|c|}{ Forest } & \multicolumn{2}{|c|}{ Restinga } & \multicolumn{2}{|c|}{ Total } \\
\hline & $\mathbf{N}$ & RF (\%) & $\mathbf{N}$ & RF (\%) & $\mathbf{N}$ & RF (\%) \\
\hline Oxysarcodexia amorosa (Schiner) & 43 & $9.64 \%$ & 9 & $2.02 \%$ & 52 & $11.66 \%$ \\
\hline Oxysarcodexia avuncula (Lopes) & 0 & $0.00 \%$ & 1 & $0.22 \%$ & 1 & $0.22 \%$ \\
\hline Oxysarcodexia fringidea (Curran \& Walley) & 0 & $0.00 \%$ & 1 & $0.22 \%$ & 1 & $0.22 \%$ \\
\hline Oxysarcodexia intona (Curran \& Walley) & 20 & $4.48 \%$ & 32 & $7.17 \%$ & 52 & $11.66 \%$ \\
\hline Oxysarcodexia morretesi Tibana \& Mello & 2 & $0.45 \%$ & 15 & $3.36 \%$ & 17 & $3.81 \%$ \\
\hline Oxysarcodexia thornax (Walker) & 39 & $8.74 \%$ & 61 & $13.68 \%$ & 100 & $22.42 \%$ \\
\hline Oxysarcodexia timida (Aldrich) & 39 & $8.74 \%$ & 39 & $8.74 \%$ & 78 & $17.49 \%$ \\
\hline Oxysarcodexia xanthosoma (Aldrich) & 2 & $0.45 \%$ & 0 & $0.00 \%$ & 2 & $0.45 \%$ \\
\hline Peckia (Peckia) chrysostoma (Wiedemann) & 35 & $7.85 \%$ & 52 & $11.66 \%$ & 87 & $19.51 \%$ \\
\hline Peckia (Sarcodexia) lambens (Wiedemann) & 9 & $2.02 \%$ & 2 & $0.45 \%$ & 11 & $2.47 \%$ \\
\hline Peckia (Squamatodes) ingens (Walker) & 2 & $0.45 \%$ & 0 & $0.00 \%$ & 2 & $0.45 \%$ \\
\hline Peckia (Euboettcheria) anguilla (Curran \& Walley) & 3 & $0.67 \%$ & 0 & $0.00 \%$ & 3 & $0.67 \%$ \\
\hline Peckia (Euboettcheria) collusor (Curran \& Walley) & 6 & $1.35 \%$ & 1 & $0.22 \%$ & 7 & $1.57 \%$ \\
\hline Peckia (Pattonella) intermutans (Walker) & 4 & $0.90 \%$ & 1 & $0.22 \%$ & 5 & $1.12 \%$ \\
\hline Peckia (Peckia) pexata (Wulp) & 4 & $0.90 \%$ & 6 & $1.35 \%$ & 10 & $2.24 \%$ \\
\hline Ravinia belforti (Prado \& Fonseca) & 4 & $0.90 \%$ & 8 & $1.79 \%$ & 12 & $2.69 \%$ \\
\hline Sarcofahrtiopsis cuneata (Townsend) & 5 & $1.12 \%$ & 0 & $0.00 \%$ & 5 & $1.12 \%$ \\
\hline Tytanogrypa (Cucullomyia) larvicida (Lopes) & 1 & $0.22 \%$ & 0 & $0.00 \%$ & 1 & $0.22 \%$ \\
\hline TOTAL & 218 & $48.88 \%$ & 228 & $51.12 \%$ & 446 & $100 \%$ \\
\hline
\end{tabular}

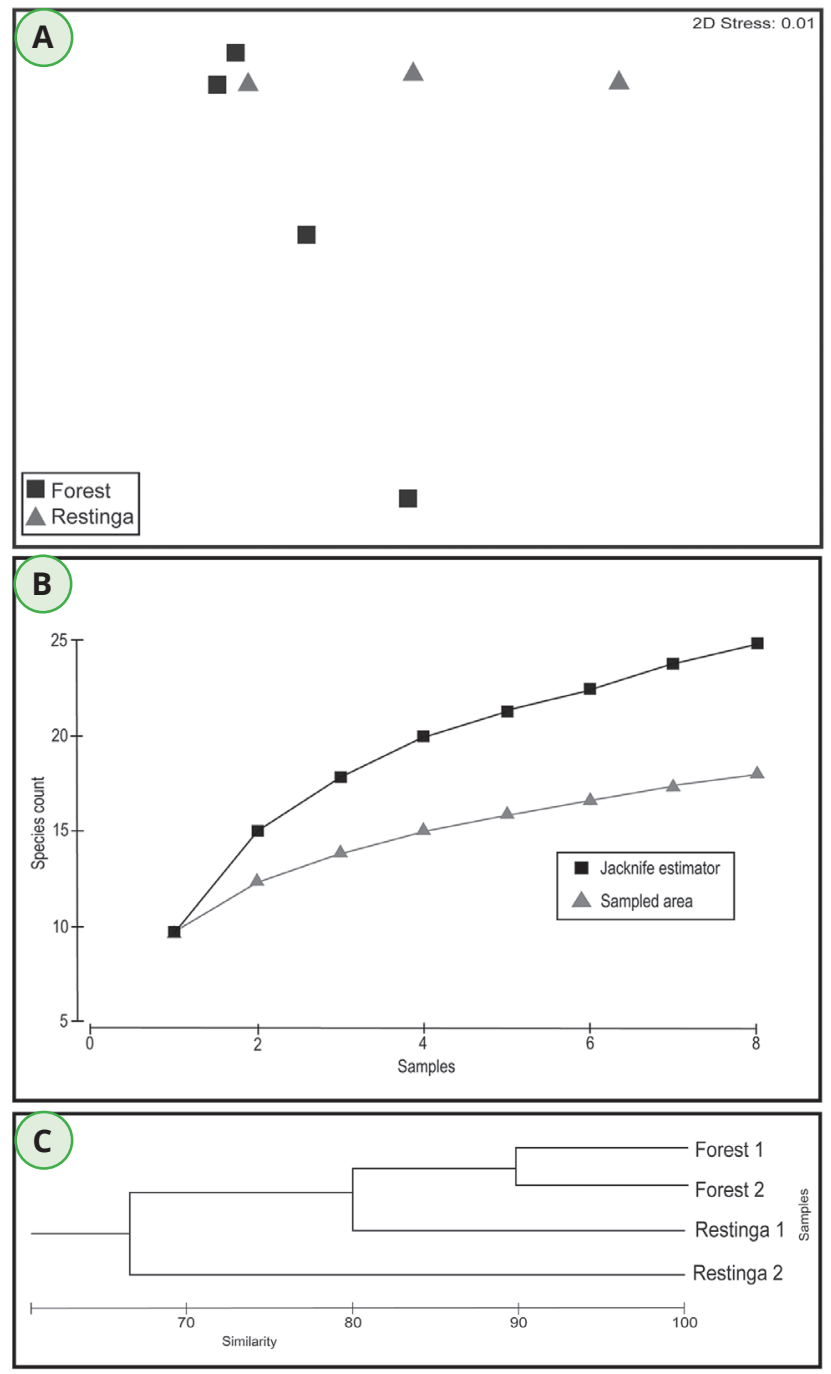

Moreover, the cluster analysis revealed that point Restinga 1 is most similar to both forest points rather than point Restinga 2 (Figure 2C), differing from the expected, which would be a higher similarity between the subsamples from each area, if the phytophysiognomy was the source of variation.

Table 2. Abundance ( $\mathrm{N}$ ) and richness (S) observed and estimated by Jackknife 2.

\begin{tabular}{ccccc}
\hline Area & N & S & $\begin{array}{c}\text { Jackknife 2 } \\
\text { estimator }\end{array}$ & $\begin{array}{c}\text { Proportion to } \\
\text { estimator }\end{array}$ \\
\hline Forest & 218 & 16 & 18.4 & $86.96 \%$ \\
\hline Restinga & 228 & 13 & 19.2 & $67.71 \%$ \\
\hline Total & $\mathbf{4 4 6}$ & $\mathbf{1 8}$ & $\mathbf{2 4 . 8}$ & $\mathbf{7 2 . 5 8 \%}$ \\
\hline
\end{tabular}

Table 3. PERMANOVA results based on Bray-curtis similarity matrix. DF $=$ degree of fredoom

\begin{tabular}{lccc}
\hline \multicolumn{1}{c}{ Source of variation } & DF & Pseudo-F & P \\
\hline Phytophysiognomy & 1 & 2.6623 & 0.058 \\
\hline Period & 1 & 2.2439 & 0.086 \\
Phytophysiognomy x Period & 1 & 1.2483 & 0.337 \\
Residue & 4 & - & - \\
\hline \multicolumn{1}{c}{ Total } & $\mathbf{7}$ & - & - \\
\hline
\end{tabular}

Figure 2. $A=$ Species accumulation curves for the collected Sarcophagidae from the Area of Relevant Ecological Interest of Itapebussus, municipality of Rio das Ostras, state of Rio de Janeiro, Brazil, with expected number of species by Jackknife 2 estimator and collected number of species. $B=$ Representation of non-metric multidimensional scaling (nMDS) of the relationships between the abundance in each sample area. Resemblance: S17 Bray Curtis similarity. C = Similarity analysis (Bray Cluster's dendrogram) of the diversity of Sarcophagidae from each sample area. Source: the authors. 


\section{DISCUSSION}

Mello-Pativ et al. (2009) identified the North and Northeast of Rio de Janeiro as priority areas for carrying out inventories of flesh flies since most municipalities in both regions have little or no collection records. The Rio das Ostras municipality had nine previously recorded species of Sarcophagidae (MelloPATIU et al. 2009). Five of them, also sampled in the present study, O. amorosa, O. thornax, O. timida, P. chrysostoma, and Ravinia belforti (Prado \& Fonseca) had already been collected in the metropolitan region of Rio de Janeiro (LEANDRO \& D'AlmEIDA 2005), indicating that they can be also common in the urban area. The other four species with previous records to Rio das Ostras municipality, Oxysarcodexia modesta Lopes, Oxysarcodexia terminalis (Wiedemann), Oxyvinia excisa (Lopes), and Tricharaea (Sarcophagula) occidua (Fabricius) were not collected in this study. The locality shown on the label of these specimens was only "Rio das Ostras" with no more details.

The region of "Baixadas Litorâneas" gathers 10 municipalities, but only four had flesh fly records, totaling 12 known species. In the present study, 12 new records were obtained for this region, increasing this knowledge by $100 \%$. In the municipality of Rio das Ostras, the knowledge of Sarcophagidae fauna increased from nine to 22 species, 13 new records obtained only in the present study.

Taxonomic works are fundamental to the knowledge about true flies' fauna in several ecosystems whose biodiversity has never been investigated. Data on true flies' fauna in restingas are still scarce, even in the state of Rio de Janeiro, where many works were carried out in this environment, but few of them involved inventories, especially entomological ones. Particularly on Sarcophagidae, is evident the absence of knowledge on species that inhabit restingas and the closest works involving flesh flies' inventories were carried out in beach environments in Northeastern Brazil, but not in restinga vegetation (BARBOSA et al. 2017).

Oxysarcodexia amorosa, O. thornax, O. timida, and $P$. chrysostoma have the potential for forensic entomology since they are recurrent in works using decaying carcasses in the state of Rio de Janeiro (Oliveira-Costa et al. 2001; Barbosa et al. 2009). Two of these species, $P$. chrysostoma and O. thornax, were also reported in human cadavers (OliveIRA-Costa et al. 2001).

Oxysarcodexia thornax is widely distributed in the state of Rio de Janeiro (Mello-Patiu et al. 2009). It is commonly found in South America, including in regions with temperature and humidity considerably distinct (MulieRI et al. 2011; Sousa et al. 2014). D'Almeida (1984) classified O. thornax as a positive synanthropic because of the preference for inhabited areas. In other regions, it was considered independent in preference (LINHARES 1981). Peckia intermutans (Walker) and Peckia collusor (Curran \& Walley) are first recorded in the Northern and Northeastern Rio de Janeiro state. Both species are potential bioindicators of environmental quality, as they were classified as asynanthropic species (LINHARES 1981; D'AlmEIDA 1984; YePESGAURISAs et al. 2013). Furthermore, P. intermutans was also found on a sandy beach with low degree of anthropization in the state of Pernambuco, Northeaster Brazil (BarbosA et al. 2017).

Although both sampled areas are somewhat humanimpacted, our results tend to indicate a higher degradation on restinga, since $O$. thornax (positive synanthropic) showed a higher abundance in this area, while $P$. intermutans and $P$. collusor (asynanthropics) had a higher abundance in the forest. This is consistent with observations made during sampling expeditions: in restinga areas bathers have unrestricted access to the beach by trails, while access to the forest is in privately owned, with controlled access. Restinga remains found in the state of Rio de Janeiro are mostly small and highly degenerate areas (Rocha et al. 2007). The small size and the high isolation rate of these fragments threaten their long-term survival, highlight the urgency to a better knowledge of these habitats and the need to invest in their conservation (TABARELli et al. 2005; Rocha et al. 2007).

The results herein obtained demonstrated that the presence of sarcophagid species considered as urban and synanthropic in Rio de Janeiro in the Atlantic Forest of Itapebussus ARIE emphasize that, despite being in a conservation unit, the fragments are somehow impacted. However, it is also possible to observe the presence of species related to a low rate of anthropization, showing that the Conservation Unit has been playing an essential role in the preservation of microenvironments in the municipality of Rio das Ostras. This confirms the need for more scientific investigation in this area, especially under conservation aspect, to understand the fauna diversity in this ARIE and assist in the formulation of public conservation policies.

\section{ACKNOWLEDGMENTS}

We especially thank Taciano Moura (UFPE) for valuable help with statistics. We are grateful to Josenilson Rodrigues (MN/ UFRJ), Marco Menezes (MN/UFRJ) and Geovane Souza (MN/ UFRJ) for the critical review of the manuscript. To FAPERJ (Fundação Carlos Chagas Filho de Amparo à Pesquisa no Estado do Rio de Janeiro (Proc. E-26/200.078/2019) for financial support. CAMP is supported by CNPq Research fellowship (grant 308951/2018-2), MMG was supported by CNPq (grant $132403 / 2018-8)$. This study comprises the monograph of the end of undergraduate course in Biological Sciences of MMG.

\section{REFERENCES}

Alves, ACF, WE dos Santos \& AJ Creão-Duarte, 2014. Diptera (Insecta) de importância forense da região Neotropical. Entomotropica, 29: 77-94.

Barbosa, TM, RFR Carmo, LP Silva, RG Sales \& SD Vasconcelos, 2017. Diversity of Sarcosaprophagous Calypratate (Diptera) on sandy beaches exposed to increasing levels of urbanization in Brazil. Environmental Entomology, 46: 460-469. DOI: https://doi.org/10.1093/ee/nvx059

Barbosa, RR, CA Mello-Patiu, RP Mello \& MMC Queiroz, 2009. New records of calyptrate dipterans (Fanniidae, Muscidae and Sarcophagidae) associated with the decomposition of domestic pigs in Brazil. Memórias do Instituto Oswaldo Cruz, 104: 923-926. DOI: https://doi.org/10.1590/S007402762009000600018

Barros, RM, CA Mello-Patiu \&JR Pujol-Luz, 2008. Sarcophagidae (Insecta, Diptera) associados à decomposição de carcaças de Sus scrofa Linnaeus (Suidae) em área de Cerrado do Distrito Federal, Brasil. Revista Brasileira de Entomologia 5: 606-609. DOI: https://doi.org/10.1590/S008556262008000400011

Byrd, JH \& JL Castner, 2001. Forensic Entomology: the utility of the arthropods in legal investigations. Boca Raton, CRC Press.

Carvalho, CJB \& CA Mello-Patiu, 2008. Key to the adults of the most common forensic species of Diptera in South America. Revista Brasileira de Entomologia 52: 390-406. DOI: https://doi.org/10.1590/S0085-56262008000300012

Carvalho, LML \& AX Linhares, 2001. Seasonality of insect succession and pig carcass decomposition in a natural Forest area in southeastern Brazil. Journal of Forensic Sciences, 46: 604- 608. DOI: https://doi.org/10.1520/ JFS15011J

D'Almeida, JM, 1984. Sinantropia de Sarcophagidae (Diptera) na região metropolitana do Rio de Janeiro. Arquivos da Universidade Federal Rural do Rio de Janeiro, 7: 101-110. 
Dias, GS, J Oliveira-Costa \& CA Mello-Patiu, 2015. New records of Sarcophagidae species (Diptera) with forensic potential in Rio de Janeiro. Revista Brasileira de Entomologia, 59: 255-256. DOI: https://doi.org/10.1016/j.rbe.2015.03.015

Leandro, MJF \& JM D'Almeida, 2005. Levantamento de Calliphoridae, Faniidae, Muscidae e Sarcophagidae em um fragmento de mata na Ilha do Governador, Rio de Janeiro, Brasil. Iheringia, Série Zoologia, 95: 377-381. DOI: https://doi.org/10.1590/S0073-47212005000400006

Linhares, AX, 1981. Synanthropy of Calliphoridae and Sarcophagidae (Diptera) in the city of Campinas, São Paulo, Brazil. Revista Brasileira de Entomologia, 25: 189-215.

Mascarenhas, G, 2004. Cenários contemporâneos da urbanização turística. Caderno Virtual de Turismo, 4: 1-11.

Mayerhofer \& Toledo, 2004. Plano de Manejo da ARIE de Itapebussus. Rio das Ostras, Secretaria de Meio Ambiente, Pesca e Agricultura.

Mello-Patiu, CA, WF Soares \& KP Silva, 2009. Espécies de Sarcophagidae (Insecta: Diptera) registradas no Estado do Rio de Janeiro. Arquivos do Museu Nacional, 67:173-188.

Mulieri, PR, LD Patitucci, JA Schnack \& JC Mariluis, 2011. Diversity and seasonal dynamics of an assemblage of sarcophagid Diptera in a gradient of urbanization. Journal of Insect Science, 11: 1-15. DOI: https://doi.org/10.1673/031.011.9101

Myers, N, RS Mittermeier, CG Mittermeier, GAB Fonseca \& J Kent, 2000. Biodiversity hotspots for conservation priorities. Nature, 403: 853-858. DOI: https://doi.org/10.1038/35002501

Oliveira-Costa, J, CA Mello-Patiu \& SM Lopes, 2001. Dípteros muscóides associados com cadáveres humanos no local da morte no estado do Rio de Janeiro, Brasil. Boletim do Museu Nacional, Série Zoologia, 464: 1-6.

Pape, T, 1996. Catalogue of the Sarcophagidae of the World (Insecta: Diptera). Stockholm, Associated Publishers.

Pape, T, V Blagoderov, MB Mostovski, 2011. Order Diptera Linnaeus, 1758. In: Zhang, ZQ (Eds). Animal biodiversity: An outline of high-level classification and survey of taxonomic richness. Zootaxa 3148: 222-229.

Pujol-Luz, JR, LC Arantes \& R Constantino, 2008. Cem anos da Entomologia Forense no Brasil (1908-2008). Revista Brasileira de Entomologia, 52: 485-492. DOI: https://doi.org/10.1590/S0085-56262008000400001

Ribeiro, MA, 2003. Turismo no estado do Rio de Janeiro: ensaio de uma topologia. GEOgraphia 5: 79-91. DOI: https://doi.org/10.22409/GEOgraphia2003.v5i10.a13456

Rocha, CFD, HG Bergallo, M Van Sluys, MAS Alves \& CE Jamel, 2007. The remnants of restinga habitats in the brazilian Atlantic Forest of Rio de Janeiro state, Brazil: habitat loss and risk of disappearance. Brazilian Journal of Biology, 67: 263-273. DOI: https://doi.org/10.1590/S151969842007000200011

Rosa, TA, MLY Babata, CM Souza, D Sousa, CA Mello-Patiu \& J Mendes, 2009. Dípteros de Interesse Forense em Dois Perfi s de Vegetação de Cerrado em Uberlândia, MG. Neotropical Entomology 38, 859-866. DOI: https://doi.org/10.1590/S1519-566X2009000600022

Shewell, GE, 1987. Sarcophagidae, p.1159-1186. In: McAlpine, JF, BV Peterson, GE Shewell, HJ Teskey, JR Vockeroth \& DM Wood (Eds). Manual of Neartic Diptera. Vol 2. Agriculture Canada Monograph, 28.

Sousa, JRP, MC Esposito, FS Carvalho-Filho \& L Juen, 2014. The potential use of sarcosaprophagous flesh flies and blowflies for the evaluation of the regeneration and conservation of forest clearings: A case study in the amazon forest. Journal of Insect Science, 14: 1-5. DOI: https://doi.org/10.1093/jisesa/ieu077

Tabarelli, M, LP Pinto, JMC Silva, MM Hirota \& LC Bedê, 2005. Desafios e oportunidades para a conservação da biodiversidade na Mata Altântica Brasileira. Megadiversidade, 1: 132-138.

Yepes-Gaurisas, D, JD Sánchez-Rodríguez, CA Mello-Patiu \& ME Wolff, 2013. Synanthropy of Sarcophagidae (Diptera) in La Pintada, Antioquia-Colombia. Revista de Biología Tropical, 61: 1275-1287.

$* * * * * * * * * *$
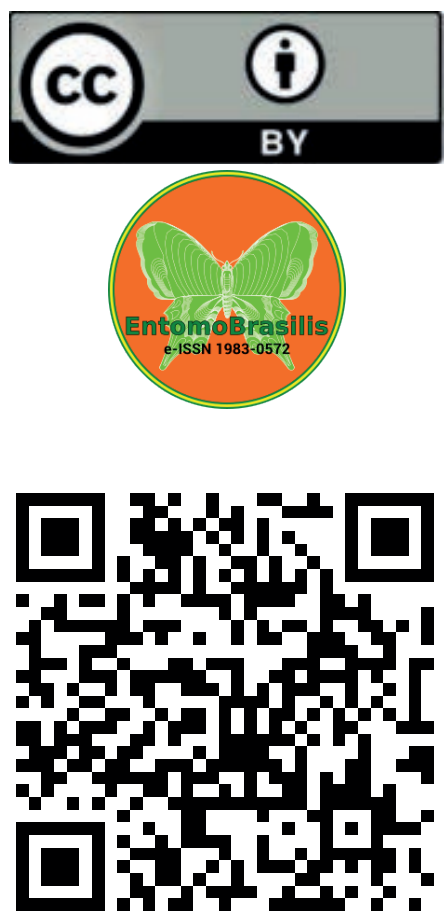